\title{
LITTER DECOMPOSITION IN A SUBARCTIC SPRUCE-LICHEN WOODLAND, EASTERN CANADA ${ }^{1}$
}

\author{
T. R. MOORE \\ Department of Geography, McGill University, \\ 805 Sherbrooke Street West, Montreal, Québec, Canada H3A 2 K6
}

\begin{abstract}
The litter bag technique was used to examine the decomposition of six litter types (representing Picea mariana, Cladina stellaris, Betula glandulosa, and Ledum groenlandicum) and standard cellulose. The decomposition was measured over a 2 -yr period, with tissue samples placed on a recently burnt site and on top of and beneath a lichen mat in a mature spruce-lichen woodland in northern Québec. Mass losses after 2 yr were between 10 and $60 \%$, with the largest losses occurring in B. glandulosa and L. groenlandicum leaves and the smallest in C. stellaris; $60-90 \%$ of the $1 \mathrm{st}-\mathrm{yr}$ mass loss occurs during the winter (September to June). The exponential decay constant $k$ ranged from -0.05 to -0.53 . There were few statistically significant differences in decomposition rate among the three sites. Of the chemical constituents analyzed, original concentrations of $\mathrm{Ca}$, carbohydrate, $\mathrm{P}, \mathrm{K}$, and $\mathrm{N}$ were closely correlated either with the decomposition parameter $k$ or with mass remaining after 1 or $2 \mathrm{yr} . \mathrm{Ca}, \mathrm{Mg}$, and $\mathrm{K}$ are rapidly lost from the decomposing tissues, except for $C$. stellaris. All the tissues, except $B$. glandulosa, showed an accumulation of $\mathrm{N}$, associated with high C: $\mathrm{N}$ ratios. The results emphasize the importance of $\mathrm{N}$ to this ecosystem, in that it tends to remain immobilized in the litter, at least over the first $2 \mathrm{yr}$.
\end{abstract}

Key words: Betula glandulosa; Cladina stellaris; decomposition; Ledum groenlandicum; litter; litter bags; nutrients; Picea mariana; subarctic; woodlands.

\section{INTRODUCTION}

The dominant vegetation association on sheltered, freely drained sites in subarctic eastern Canada is the spruce-lichen woodland, which covers over $250000 \mathrm{~km}^{2}$ in Labrador-Québec. The woodland consists of scattered spruce trees, mainly Picea mariana (black spruce), with a few Picea glauca (white spruce) and Larix laricina (tamarack), and with an understory of Betula glandulosa (dwarf birch) and Ledum groenlandicum (Labrador tea). The ground flora consists of lichens, mainly Cladina stellaris, mosses such as $P_{O}$ lytrichium juniperinum and Hylcomium splendens, and ericaceous plants such as Vaccinium uliginosum.

The woodland is characterized by low biomass, low overall primary productivity, low nutrient status, and susceptibility to fire. Few nutrients enter the system through precipitation $\left(5 \mathrm{~kg} \cdot \mathrm{ha}^{-1} \cdot \mathrm{yr}^{-1}\right)$, release of minerals by soil weathering is very limited, leaching losses from the soil column are also small $\left(\approx 10 \mathrm{~kg} \cdot \mathrm{ha}^{-1} \cdot \mathrm{yr}^{-1}\right)$, and the postfire nutrient flush is small (Moore 1980, Dubreuil and Moore 1982). Many of the soil's available nutrients are tied up in organic matter, which has been shown to decompose slowly, mainly because of the low soil temperatures, the low soil $\mathrm{pH}$, and the paucity of readily available $\mathrm{N}$ (Moore 1981). The black spruce trees have low nutrient concentrations in the needles (Rencz 1976) and increase their growth rate when treated with $\mathrm{N}$ and $\mathrm{P}$ fertilizers (Cowles 1982). The growth rate of the shrub $L$. groenlandicum, and to a lesser extent $B$. glandulosa, also responds to fertiliza-

${ }^{1}$ Manuscript received 11 May 1982; revised 24 January 1983; accepted 28 February 1983. tion (T. I. Prudhomme, personal communication), but the addition of fertilizers to the lichen results in little change in growth rate (Carstairs and Oechel 1978).

The subarctic spruce-lichen woodland, then, is limited by nutrient availability, so that litter decomposition and nutrient release are important, yet data are lacking on these two aspects. In this paper, through a litter bag decomposition study, I address three main questions.

1) At what rates do different litter types decompose, and does the position of the litter on the woodland floor affect these rates?

2) What chemical properties of the litter types appear to control the rates of decomposition, and how do the observed rates compare to other studies, from which predictive models have been developed?

3) At what rates are nutrients released from the decomposing litters?

\section{Methods \\ Area of study}

The study was conducted at two sites located $25 \mathrm{~km}$ northwest of Schefferville in northern Québec $\left(54^{\circ} 43^{\prime} \mathrm{N}\right.$, $66^{\circ} 42^{\prime} \mathrm{W}$ ). One site represents a mature woodland, estimated to have been burnt at least $110 \mathrm{yr}$ ago (the 105 $\mathrm{yr}$ site of Moore [1980]); the lichen mat is $5-10 \mathrm{~cm}$ thick. There are $\approx 500$ trees/ha at this site that are $>5$ $\mathrm{cm} \mathrm{dbh;78 \%} \mathrm{are} \mathrm{P.} \mathrm{mariana,} 16 \%$ P. glauca, and $6 \%$ L. laricina. The second site is located in an adjacent woodland, which burned $8 \mathrm{yr}$ prior to the start of the study. All the spruce trees were killed by the fire, but the scorched trunks remain upright. Regeneration has been slow, with the soil surface bare except for $B$. 
glandulosa and a few grasses and mosses. The soils are shallow and acid, with a thin $(5-10 \mathrm{~cm})$ layer of organic matter resting on the subsoil and are classified as Dystric Cryochrepts (Soil Survey Staff 1975) or Eluviated Dystric Brunisols (Canada Soil Survey Committee 1978).

The climate of the Schefferville region is characterized by cold winters (January mean $-22^{\circ} \mathrm{C}$ ) and cool summers (July mean $12{ }^{\circ} \mathrm{C}$ ); the soils are thawed from early June to late September. Of the mean annual precipitation of $785 \mathrm{~mm}, 407 \mathrm{~mm}$ falls as rain, mainly between May and October (Barr and Wright 1981). For the duration of the study from June 1979 to September 1981 , the air temperatures showed no major deviation from the long-term (25-yr) mean. There was, however, 18 and $14 \%$ more rain than average from June to September, 1979 and 1980, respectively, and $11 \%$ less rain than average from June to September 1981. The winters of 1979-1980 and 1980-1981 received 32 and $65 \%$ more snow than average. Thus, the study period involved wetter summers and thicker snow covers than average.

Actual evapotranspiration from a lichen-covered surface is estimated to be $180-200 \mathrm{~mm} / \mathrm{yr}$, and that from a bare or recently burnt site $200-220 \mathrm{~mm} / \mathrm{yr}$ (Wright 1981). When combined with winter evaporation and snow sublimation, the annual actual evapotranspiration is probably close to $300 \mathrm{~mm}$. Beneath the lichen mat, the soils remain at or near field capacity for most of the summer, but on the burn site, the soil surface is drier and warmer, and with larger temperature fluctuations during the summer (Rouse and Kershaw 1971, Moore, 1980, S. Cowles, personal communication).

\section{Field methods}

The litter bag method is very commonly used for decomposition studies, though it suffers from drawbacks (Swift et al. 1979). In particular, use of the mesh bags can alter the microclimate around the decomposing litter, exclude important components of the decomposer community, or allow particles of litter to fall through the mesh. The microclimate of the bags located beneath the lichen mat is unlikely to be different from that of the unconfined litter, but the litter on the surface of the lichen mat or on the burn soil may be kept moister than unconfined litter. The use of 1-mm mesh size is common in many studies of decomposition; it is sufficiently small to prevent major losses of litter, though, for example the needles of L. laricina fall through readily (and hence this tissue was not used in this study). Furthermore, Lucarotti (1981) has shown that the macrofaunal population of woodland soils is low, so the mesh bags probably do not exclude any important decomposers. Hence, the data from 1-mm mesh bags conform to other decomposition studies and are probably minimal estimates of true decomposition rates.
Litter bags, $20 \times 20 \mathrm{~cm}$, were made of nylon mesh with 1-mm holes. Six tissue types were collected:

1) P. mariana needles collected fresh from a tree;

2) old $P$. mariana needles, which had aged and browned on the tree before being collected;

3) small (2-10 $\mathrm{mm}$ diameter) $P$. mariana twigs:

4) C. stellaris;

5) leaves of $B$. glandulosa;

6) leaves of $L$. groenlandicum.

Samples of (1) to (4) were collected in early June 1979, while (5) and (6) were collected in mid-September 1979. The samples were oven-dried overnight at $65^{\circ} \mathrm{C}$, and $3-10 \mathrm{~g}$ were placed in the litter bags.

In addition to the above tissues, $5 \times 5 \mathrm{~cm}$ strips of Borregaard photographic cellulose were used after oven-drying at $105^{\circ} \mathrm{C}$ (Rosswall 1974). The cellulose was used to provide data on the decomposition of a standard material, so that rates can be compared with studies in other ecosystems.

Litter input from $P$. mariana and $C$. stellaris can be expected to occur throughout the year; Werren (1978) shows that around spruce trees, about five times as much litter reaches the ground during winter (September to June) as in the summer. Thus, placement of the spruce and lichen samples was made in June, along with the cellulose strips. B. glandulosa and L. groenlandicum lose their leaves mainly during the fall, so samples of these two species were placed out in midSeptember.

Plant litter falls onto the lichen mat surface and then works its way down to the soil surface, as the mat expands and contracts upon wetting and drying. For this reason, litter bags were placed on top of and beneath the lichen mat at the woodland site and away from trees to minimize microclimatic or litter fall effects. At the burn site, the bags were placed on the soil surface.

Litter bags were collected in early September 1979 and in early June and early September of 1980 and 1981 , with four replicates for each litter type and each site at each sampling.

\section{Analvtical methods}

After collection, the litter bags were oven-dried at $65^{\circ}$ (except for the cellulose dried at $105^{\circ}$ ) and the remaining litter removed and weighed. In addition, the annual decomposition constant $k$ (Olson 1963) for the exponential relationship has been calculated, using the equation:

$$
\ln \left(\frac{x_{0}}{x_{t}}\right)=k t
$$

where $x_{0}$ is the original amount of litter, $x_{t}$ is the amount of litter remaining after time $t$, and $t$ is the time (in years).

$k$ values were calculated by a linear regression of $\ln$ $\left(x_{0} / x_{t}\right)$ vs. time. The $k$ values represent a 2.25 -yr period 
TABLE 1. Calculated $k$ values, with $95 \%$ confidence interval (in parentheses) and coefficient of determination $\left(r^{2}\right)$ and proportion of original litter mass remaining after $2 \mathrm{yr}$, for the three sites.

\begin{tabular}{|c|c|c|c|c|c|c|c|c|c|}
\hline \multirow[b]{3}{*}{ Tissue } & \multicolumn{9}{|c|}{ Site } \\
\hline & \multicolumn{3}{|c|}{ Top of lichen mat } & \multicolumn{3}{|c|}{ Beneath lichen mat } & \multicolumn{3}{|c|}{ Burn } \\
\hline & $k$ & $r^{2}$ & $\begin{array}{l}\text { Propor- } \\
\text { tion re- } \\
\text { maining }\end{array}$ & $k$ & $r^{2}$ & $\begin{array}{l}\text { Propor- } \\
\text { tion re- } \\
\text { maining }\end{array}$ & $k$ & $r^{2}$ & $\begin{array}{l}\text { Propor- } \\
\text { tion re- } \\
\text { maining }\end{array}$ \\
\hline Picea needles & $-0.20( \pm 0.05)$ & 0.83 & 0.58 & $-0.17( \pm 0.03)$ & 0.88 & 0.55 & $-0.24( \pm 0.08)$ & 0.81 & 0.53 \\
\hline Picea old needles & $-0.15(+0.05)$ & 0.83 & 0.71 & $-0.14( \pm 0.02)$ & 0.94 & 0.68 & $-0.17( \pm 0.04)$ & 0.88 & 0.66 \\
\hline Picea twigs & $-0.10( \pm 0.02)$ & 0.88 & 0.72 & $-0.09( \pm 0.02)$ & 0.85 & 0.71 & $-0.14( \pm 0.04)$ & 0.85 & 0.67 \\
\hline Cladina & $-0.04( \pm 0.02)$ & 0.55 & 0.88 & $-0.14( \pm 0.05)$ & 0.69 & 0.68 & $-0.05( \pm 0.04)$ & 0.40 & 0.85 \\
\hline Betula leaves & $-0.17( \pm 0.08)$ & 0.66 & 0.51 & $-0.30( \pm 0.21)$ & 0.53 & 0.51 & $-0.45( \pm 0.09)$ & 0.90 & 0.42 \\
\hline Ledum leaves & $-0.31( \pm 0.10)$ & 0.79 & 0.56 & $-0.53( \pm 0.20)$ & 0.79 & 0.53 & $-0.33( \pm 0.06)$ & 0.92 & 0.59 \\
\hline Cellulose & $-0.34( \pm 0.22)$ & 0.37 & 0.42 & $-0.47( \pm 0.34)$ & 0.37 & 0.67 & $-0.13( \pm 0.07)$ & 0.58 & 0.74 \\
\hline
\end{tabular}

(June 1979 to September 1981), except for the Betula and Ledum leaves, where the period was $2.0 \mathrm{yr}$.

The tissue samples were ground to pass through a $0.2-\mathrm{mm}$ sieve and digested in a strong $\mathrm{H}_{2} \mathrm{SO}_{4} / \mathrm{HClO}_{4}$ mixture until clear. $\mathrm{Ca}, \mathrm{Mg}$, and $\mathrm{K}$ in the extract were determined by atomic absorption spectrophotometry, P by the yellow vanadomolybdate method (Hesse 1971), and $\mathrm{N}$ by the Nesslerization method (Middleton 1960). $\mathrm{C}: \mathrm{N}$ ratios were calculated, assuming that $\mathrm{C}$ forms $48 \%$ of the tissue mass (Swift et al. 1979). The quantity of each element remaining at each sampling date was calculated, using the concentration of nutrient in the tissue and the mass of the remaining tissue. The quantity of each element is then expressed as a percentage of the amount contained in the original tissue.

Samples of the original tissues were analyzed for the five macronutrients and also for acid-detergent fiber, lignin, and cellulose by the decahydronaphthalene-potassium permanganate-ignition method (Goering and van Soest 1970). The original tissue was also analyzed for total extractable phenolics and carbohydrates extracted overnight by a $50 \%$ methanol solution in the

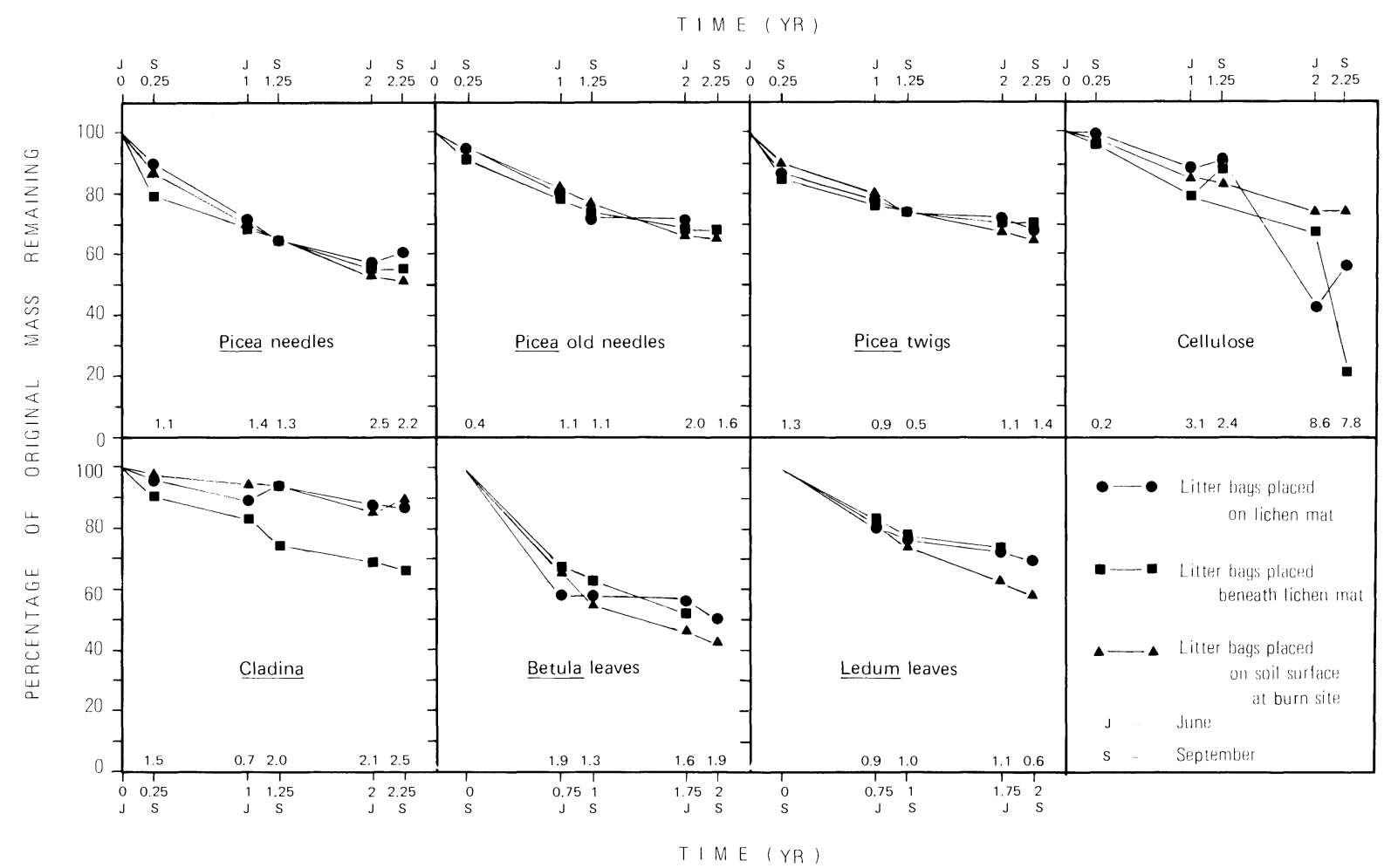

FIg. 1. Changes in mass of the six tissue types, plus cellulose strips, contained in the litter bags. Each point represents four replicate litter bags. The numbers inside the bottom of each graph are the average standard error of the mean (\%) for each tissue type at each sampling date. The month of sampling is indicated below each number on the time scale. 
TABLE 2. Chemical composition of the original tissues. ADF $=$ acid detergent fiber. Phenolics are expressed as equivalent to salicylic acid. Carbohydrates are expressed as equivalent to dextrose.

\begin{tabular}{|c|c|c|c|c|c|c|c|c|c|c|c|}
\hline Tissue & $\begin{array}{c}\mathrm{Ca} \\
(\%)\end{array}$ & $\begin{array}{l}\mathrm{Mg} \\
(\%)\end{array}$ & $\begin{array}{c}\mathrm{K} \\
(\%)\end{array}$ & $\begin{array}{c}\mathrm{N} \\
(\%)\end{array}$ & $\begin{array}{l}\mathrm{C}: \mathrm{N} \\
\text { ratio }\end{array}$ & $\begin{array}{c}\mathrm{P} \\
(\%)\end{array}$ & $\begin{array}{c}\mathrm{ADF} \\
(\%)\end{array}$ & $\underset{(\%)}{\text { Lignin }}$ & $\begin{array}{c}\text { Cellu- } \\
\text { lose } \\
(\%)\end{array}$ & $\begin{array}{l}\text { Phe- } \\
\text { nolics } \\
\text { (mg/g) }\end{array}$ & $\begin{array}{c}\text { Car- } \\
\text { bohy- } \\
\text { drates } \\
(\mathrm{mg} / \mathrm{g})\end{array}$ \\
\hline Picea needles & 0.30 & 0.05 & 0.29 & 0.47 & $102: 1$ & 0.080 & 71 & 10 & 19 & 100 & 492 \\
\hline Picea old needles & 0.29 & 0.04 & 0.21 & 0.46 & 98:1 & 0.090 & 57 & 19 & 24 & 300 & 265 \\
\hline Picea twigs & 0.17 & 0.06 & 0.25 & 0.25 & 192:1 & 0.074 & 50 & 21 & 29 & 500 & 270 \\
\hline Cladina & 0.03 & 0.01 & 0.08 & 0.19 & $253: 1$ & 0.033 & 88 & 04 & 08 & 10 & 8 \\
\hline Betula leaves & 0.32 & 0.14 & 0.28 & 0.75 & $64: 1$ & 0.204 & 65 & 20 & 15 & 1175 & 460 \\
\hline Ledum leaves & 0.35 & 0.08 & 0.36 & 1.23 & $39: 1$ & 0.140 & 60 & 23 & 17 & 1050 & 387 \\
\hline
\end{tabular}

ratio 100:1 (extractant volume : tissue mass); concentrations of phenolics and carbohydrates are expressed as the equivalents of salicylic acid and dextrose, with the determination made colorimetrically by the FolinDenis and anthrone methods (Anderson 1973, Schlesinger and Hasey 1981).

\section{Results \\ Mass loss}

There is considerable variation in the mass loss between tissue types (Table 1). After $2.25 \mathrm{yr}$, the lichen placed on top of the lichen or the burn site lost only $10-15 \%$, whereas $45-55 \%$ of the mass of Betula leaves disappears over a 2-yr period. $k$ values range from -0.05 for lichen placed on the lichen mat surface or the burn site, to over -0.3 for Betula and Ledum leaves. In general, the Betula and Ledum leaves are most rapidly decomposed, followed by the Picea needles, the Picea old needles and twigs, and finally the Cladina. The cellulose behaves similarly to the Betula and Ledum leaves.

In some tissue types, especially the cellulose and Cladina, there is a high degree of variation in mass loss between replicates, resulting in high standard errors in the calculation of the $k$ values. As a result, there are few statistically significant differences in $k$ values for the tissue types placed at the three sites, despite the major microclimatic differences anticipated between the sites. The only strong difference is the much faster breakdown of lichen beneath the mat (where most lichen litter accumulates).

Use of the $k$ value to express the decomposition rate is dependent on the expectation that the decomposition will follow an inverse exponential pattern. While such a pattern is evident in the Betula leaves, it is not apparent in the other tissue types. In fact, a linear regression between mass loss and time gives as good a prediction as the exponential relationship for 12 of the 21 tissue-site types.

Much of the mass loss occurs from September to June, i.e., the winter months, when the surface is covered by up to $1.5 \mathrm{~m}$ of snow (Fig. 1). Of the 1st-yr mass loss, the winter accounts for between 60 and $90 \%$, in most cases, except for the Picea twigs, which lose only $29-54 \%$ of their 1st yr mass loss during the September-June period.

Nutrient concentrations are low in the Picea and Cladina samples but are higher in the Betula and Ledum leaves (Table 2). C: $\mathrm{N}$ ratios are high throughout, ranging from 39:1 in the Ledum leaves to 253:1 in the Cladina. There is also a wide range in concentration of the organic constituents; lignin content is highest in the Betula and Ledum leaves and Picea twigs, and lowest in the lichen. Phenolics are also highest in the Betula and Ledum leaves, while carbohydrates are more equably distributed, except for the Cladina.

Table 3 contains the correlation matrix of $k$ values and proportion of mass remaining after 1 and $2 \mathrm{yr}$ of each litter type against the chemical composition of the original tissue. No one chemical constituent provides an excellent correlation with the decomposition parameters, but $\mathrm{Ca}$, carbohydrate, and $\mathrm{P}$ are most frequently correlated, followed by $\mathrm{K}$ and $\mathrm{N}$. The analysis shows that the type of decomposition parameter used affects the degree of correlation. For example, $\mathrm{N}$ content is strongly correlated with the decomposition parameter $k$, but not with the proportion of mass remaining after 1 or $2 \mathrm{yr}$, whereas $\mathrm{P}$ shows the reverse pattern.

\section{Nutrient changes}

Potassium is the nutrient most rapidly lost from the decomposing tissues (Fig. 2). About $50 \%$ of the original $\mathrm{K}$ is lost during the first summer or winter, and only $10-20 \%$ of the original $\mathrm{K}$ is left in the tissues after $2 \mathrm{yr}$. The exception to this pattern occurs in the Cladina tissue, where samples placed beneath the lichen mat lose $\mathrm{K}$ at a slower rate but have only $30 \%$ of their original $\mathrm{K}$ left after $2 \mathrm{y}, \mathrm{r}$, whereas samples placed on the lichen mat or at the burn site retain nearly all of their original $\mathrm{K}$ over the $2 \mathrm{yr}$.

Calcium and $\mathrm{Mg}$ are lost more slowly from the decomposing tissues, which retain $15-50 \%$ of their original content after $2 \mathrm{yr}$ (Fig. 2). One exception to this pattern occurs in the Picea needles, which show an increase of $18-20 \%$ Ca over the first 3 mo (June-September), after which there is a rapid decline. This early increase may be attributed to the occurrence of cal- 


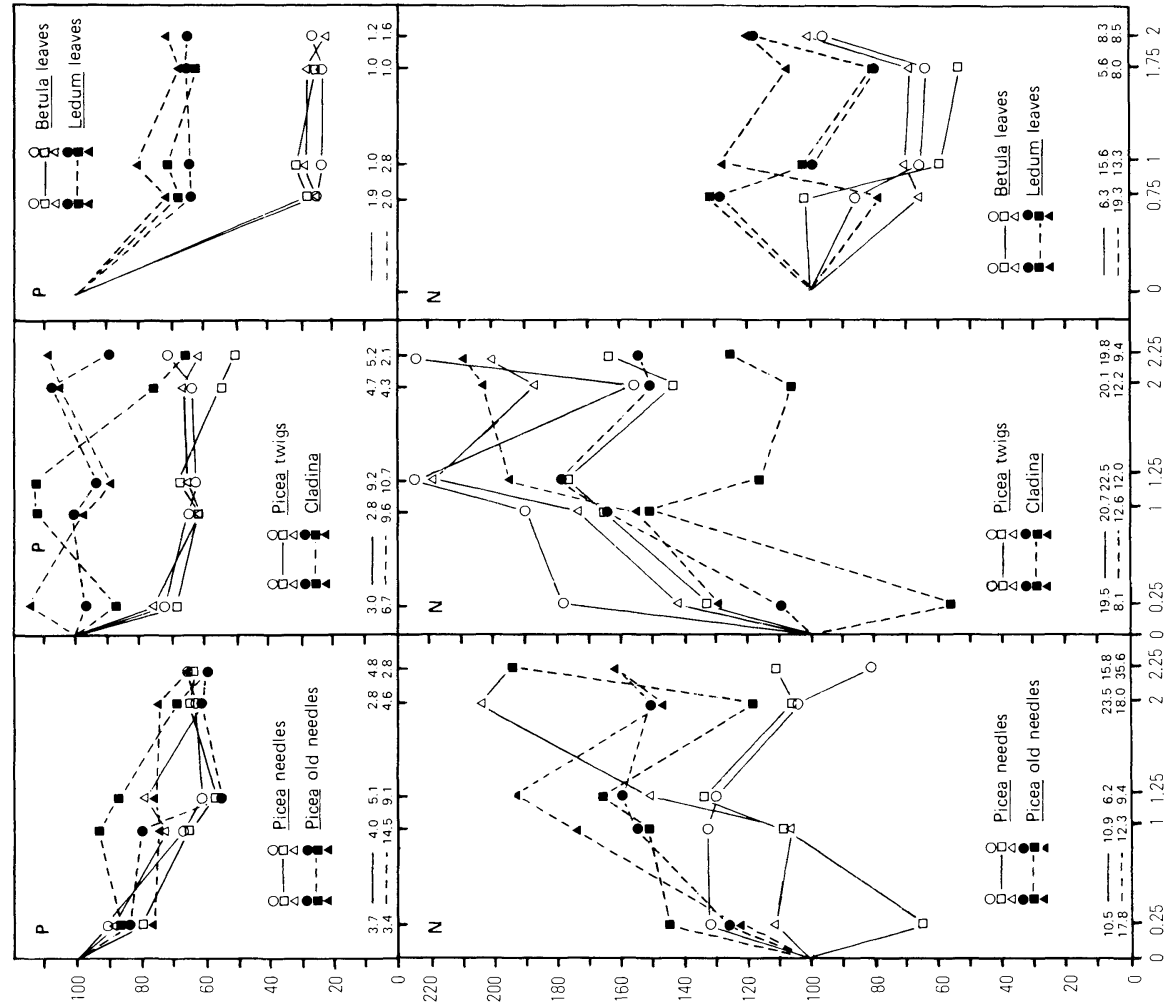

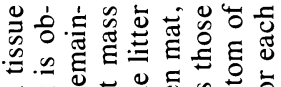

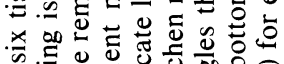

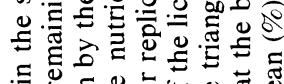

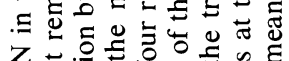
둘. S.

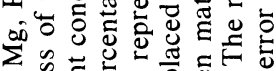

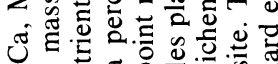

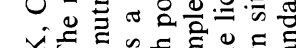

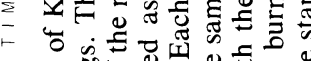

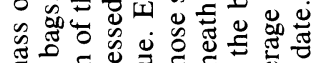
है.

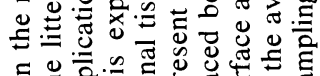

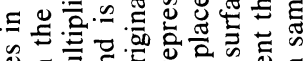

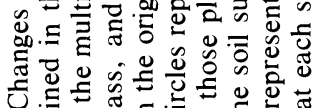

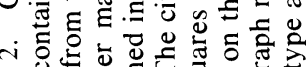
ن

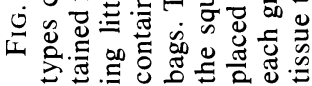

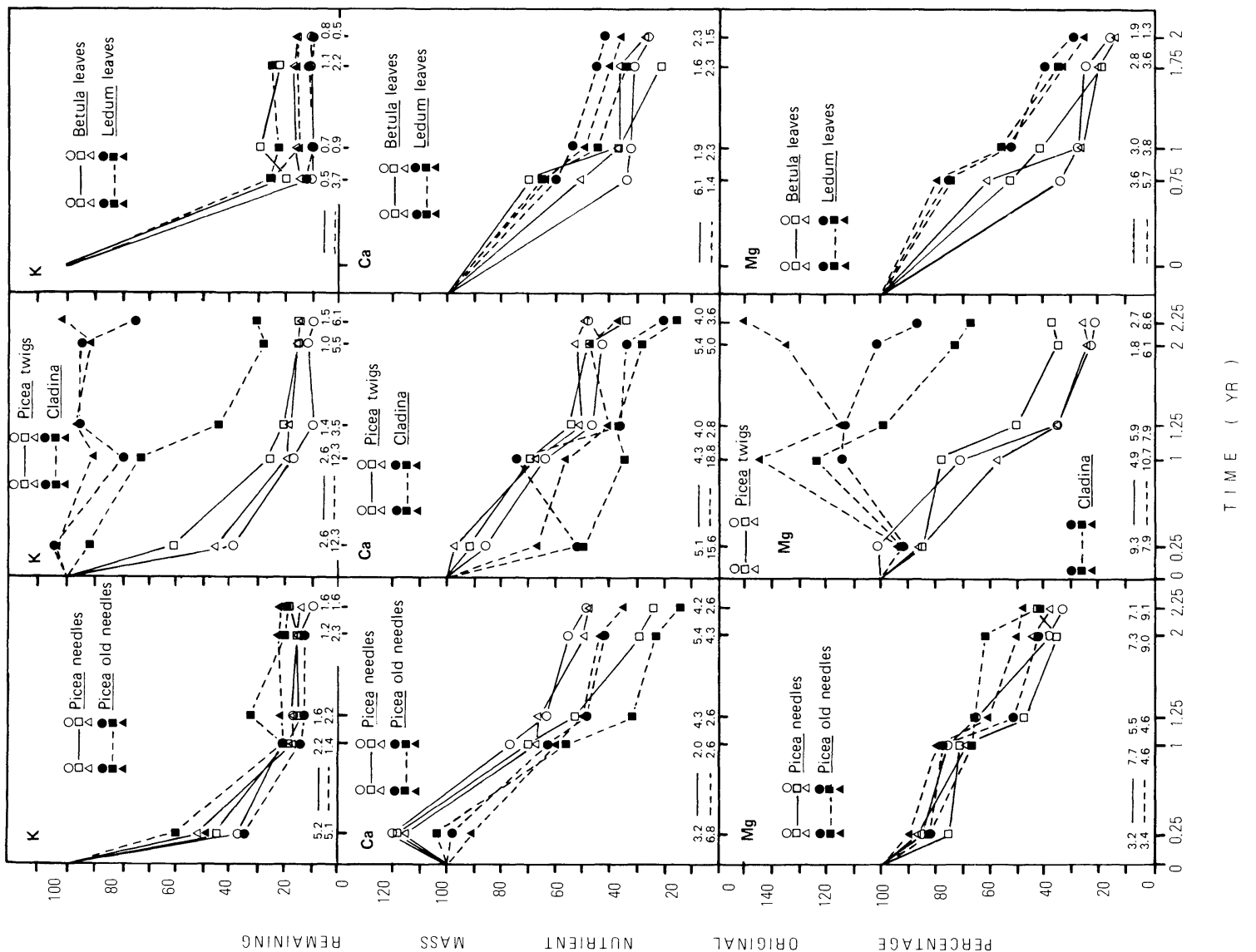


TABLE 3. Pearson product-moment Matrix of correlations between decomposition parameters and chemical properties (described in Table 2 ) of the six tissue types. Correlation coefficients significant at $P<.05$ are underlined.

\begin{tabular}{|c|c|c|c|c|c|c|c|c|c|c|c|}
\hline \multirow[b]{2}{*}{$\begin{array}{l}\text { Param- } \\
\text { eter* }\end{array}$} & \multicolumn{11}{|c|}{ Chemical property of original tissue } \\
\hline & $\mathrm{Ca}$ & $\mathrm{Mg}$ & $\mathrm{K}$ & $\mathrm{N}$ & $\mathrm{P}$ & ADF & Lignin & Cellulose & Phenolics & $\begin{array}{c}\text { Carbo- } \\
\text { hydrates }\end{array}$ & $\underset{\text { ratio }}{\text { Lignin/N }}$ \\
\hline$k_{t}$ & -.814 & -.935 & -.761 & -.755 & -.970 & .390 & -.570 & .057 & -.856 & -.815 & .382 \\
\hline$k_{b}$ & -.597 &.$- \overline{521}$ & -.690 & $-\overline{966}$ &.$- \overline{632}$ & .102 & -.466 & .292 & $-\overline{.745}$ & $-\overline{411}$ & .405 \\
\hline$k_{b u}$ & -.867 & -.461 & -.897 & -.924 & -.576 & .376 & -.570 & -.100 & -.595 & -.730 & .327 \\
\hline$P_{1 t}$ & -.783 & -.447 & -.681 & $-\overline{487}$ & -.887 & .382 & -.524 & -.159 & -.688 & -.884 & .084 \\
\hline$P_{1 b}$ & -.693 & -.544 & -.607 & -.422 & -.837 & .218 & -.362 & -.025 & -.617 & -.864 & .229 \\
\hline$P_{1 b u}$ & -.686 & -.460 & -.605 & -.405 & -.863 & .295 & -.435 & -.090 & -.659 & -.841 & .120 \\
\hline$P_{2 t}$ & -.845 & -.540 & -.763 & -.552 & -.854 & .397 & -.526 & -.183 & -.664 & -.947 & .241 \\
\hline$P_{2 b}$ & -.585 & .103 & -.601 & -.869 & -.870 & -.086 & -.498 & .354 & -.900 & -.448 & .672 \\
\hline$P_{2 b u}$ & -.894 & -.600 & -.857 & $-\overline{691}$ & -.807 & .355 & -.509 & -.124 &.$- \overline{657}$ & -.973 & .166 \\
\hline
\end{tabular}

* Key: $k=$ decomposition constant; $P_{1}, P_{2}=$ proportion of original mass remaining after 1 and 2 yr, respectively; $t=$ sample placed on top of lichen mat; $b=$ sample placed beneath lichen mat; $b u=$ sample placed on burn soil.

cium oxalate (Graustein et al. 1977). A second exception is the Cladina, which shows a pronounced loss of Ca to only $15-40 \%$ of the original value after $2 \mathrm{yr}$, whereas the loss of $\mathrm{Mg}$ is small at the two woodland sites, and there is a gain of $\mathrm{Mg}$ at the burn site.

The pattern of change in $\mathrm{P}$ is more complex than for $\mathrm{K}, \mathrm{Mg}$, or Ca. In the Picea tissues and the Betula and Ledum leaves, there is a pronounced decrease in $\mathrm{P}$, so that only $25-70 \%$ of the original $P$ remains after 2 $\mathrm{yr}$. The decrease is most rapid for the Betula and Ledum leaves, where nearly all of the 2-yr loss occurs during the first winter. The pattern of $\mathrm{P}$ in the Cladina tissue is highly variable, with large standard errors of the mean for each sampling date, so no trend can be established; though, in general, the Cladina appears to retain nearly all of its original $P$.

The changes in $\mathrm{N}$ show the most interesting and important pattern, though there are higher standard errors for $\mathrm{N}$ than for any other element. The Betula leaves show an initial loss of $\mathrm{N}$, which is most pronounced for the samples placed on the burn site and on top of the lichen mat. Further loss of $\mathrm{N}$ occurs until, after $21 \mathrm{mo}$, the tissue retains only $55-70 \%$ of its original N. However, at the 24-mo sampling date, there is an increase in $\mathrm{N}$ back to quantities close to that originally contained in the tissue. All the other tissue types show an increase of $\mathrm{N}$ over the original tissue quantities.

The Picea tissues all show increases in both $\mathrm{N}$ concentration and quantity, with increases in quantity of up to $200 \%$ of the original after $2 \mathrm{yr}$. The same pattern is exhibited with the lichen tissue, although there is a high standard error of the mean for replicates; again, accumulations of $\mathrm{N}$ of up to $200 \%$ are observed after $2 \mathrm{yr}$. The Ledum leaves also show increases in the quantity of $\mathrm{N}$ though the pattern is not so pronounced, and the increases are only $20 \%$ after $2 \mathrm{yr}$.

There is a good relationship between changes in the amount of $\mathrm{N}$ in the tissue, and the original $\mathrm{C}: \mathrm{N}$ ratio.
The tissues with the lowest $\mathrm{C}: \mathrm{N}$ ratios (Betula and Ledum leaves) show little or no increase in $\mathrm{N}$ amount (though they do show an increase in $\mathrm{N}$ concentration in the tissue). The samples with the highest $\mathrm{C}: \mathrm{N}$ ratios also show the largest proportional increases in $\mathrm{N}$ amount. However, inspection of $\mathrm{C}: \mathrm{N}$ ratios shows that there is no one critical ratio at which there is a change from $\mathrm{N}$ net immobilization to net mineralization. After $2 \mathrm{yr}$, the C:N ratios in the remaining Betula and Ledum leaves range from 19:1 to $32: 1$, yet there is little evidence of large amounts of net $\mathrm{N}$ mineralization. For the other four tissues, after 2 yr the $\mathrm{C}: \mathrm{N}$ ratios range from 40:1 to 80:1 for the Picea tissues to over 100:1 for the Cladina tissue.

\section{Discussion}

The mass loss over the 2-yr period ranged from an average of $20 \%$ for Cladina tissue to $52 \%$ for the Betula leaves, representing exponential decay constant values $(k)$ of between -0.08 and -0.31 . These losses are similar to those observed in other northern ecosystems. In this study, the Picea needles lost $12-25 \%$ and $28-30 \%$ of their mass over 1 and $2 \mathrm{yr}$, respectively, compared to losses of $10-15 \%$ over $1 \mathrm{yr}$ and $25 \%$ over 2 yr recorded by Weetman (1965) in a boreal forest near Baie Comeau, Québec, and 10\% over 1 yr in Picea glauca needles in Alaska (Piene and van Cleve 1978). At a lichen heath tundra site at Hardangervidda, Norway, lichen tissue lost $10-15 \%$ of its mass over 2 yr (Heal and French 1974), compared to the 13-32\% observed in this study. In a mire near Abisko, Sweden, Betula nana leaves lost 21-30\% over 1 yr (Heal and French 1974), compared to 1-yr losses of B. glandulosa of $37-45 \%$ in this lichen woodland study.

The environmental constraints on decomposition can be more validly compared by looking at the mass loss of cellulose strips, though not all decomposition studies use this standard material. In the Alaskan forest study, Piene and van Cleve (1978) observed mass loss- 
es of $8-57 \%$ after $1 \mathrm{yr}$, the lowest value being found in samples placed on the surface of the soil, while the highest values were found when the cellulose was placed in the cooler, wetter organic horizons. In this study, mass loss after $1 \mathrm{yr}$ amounted to $12-20 \%$. For tundra ecosystems, very variable cellulose mass losses have been observed, from $<1 \%$ to over $30 \%$ in $1 \mathrm{yr}$ (Rosswall 1974). When the mean annual precipitation $(P)$ and the temperature $(T)$ sum (degree-days $>0{ }^{\circ} \mathrm{C}$ ) parameters are used for Schefferville $(P=785 \mathrm{~mm}$; $T=1140$ degree-days), the decomposition rates for cellulose are in general agreement with those observed at tundra sites with similar climates.

While there are major differences in the decomposition rates between different tissue types, there are few significant differences in decomposition rates for the same tissue type located on the burn soil site, on the lichen mat or beneath the lichen mat. In part, this is due to the high standard errors associated with the regression coefficients $(k)$, the only major differences being the high decomposition rates of Cladina beneath the lichen mat and Betula leaves on the burn soil. In addition, the cellulose beneath the lichen mat shows a greater mass loss after 2 yr than the other two sites, though this is not borne out by significant differences in the $k$ values. The Cladina litter accumulates naturally beneath the lichen mat, so this value $(k=-0.14)$ should be taken as representative of Cladina litter. The absence of many, consistent differences in decomposition rates between sites is surprising, given the microclimatic differences, and previous studies which have shown microclimate to exert a strong control on decomposition rate (e.g., Weetman 1965, Piene and van Cleve 1978, Edmonds 1980). Two reasons may account for this absence. One is that much of the decomposition occurs during the winter months, when microclimatic differences would be obscured by the snow cover, and the second is that the warmer and drier conditions on the burn soil site or on top of the lichen mat may be compensated by the cooler, but wetter, conditions beneath the lichen mat.

In decomposition studies, attention has been directed to establishing the important parameters (both climatic and tissue quality) which control decomposition rates, so that predictive models can be constructed. In this study, it has been shown that although some nutrients, especially $\mathrm{Ca}, \mathrm{P}, \mathrm{K}$, and $\mathrm{N}$ are correlated with some decomposition parameters, the relationship does not hold for all parameters. Of the organic components of the tissue, only carbohydrate content is related to the decomposition parameters. In a study of decomposition rates (expressed as percent of the mass remaining after $2 \mathrm{yr}$ ) at a variety of tundra sites, van Cleve (1974) found that these rates were correlated with lignin content, $\mathrm{C}: \mathrm{N}$ ratio, and $\mathrm{Ca}$ and $\mathrm{K}$ contents, but not $\mathrm{N}$ and $\mathrm{P}$ contents. Melillo et al. (1982) have shown that the lignin: $N$ ratio provides a strong correlation with the decomposition of litter in a hardwood forest, using both the mass remaining after $1 \mathrm{yr}$ and the decomposition parameter $k$. The lack of general agreement on the important chemical constituents controlling litter decomposition rates may be related, in part, to the use of different decomposition parameters, as well as to the multiple-factorial effects of nutrients (Swift et al. 1979).

Lignin does not appear to have an important control on the decomposition rates of the six tissue types; neither lignin nor lignin:nitrogen ratio is significantly correlated with any of the decomposition parameters, though several other studies have identified the importance of lignin in retarding decomposition rates (e.g., van Cleve 1974, Meentemeyer 1978, Melillo et al. 1982). In part, the absence of a significant relationship may be due to the small range of lignin contents observed (10-23\%), except for Cladina. In this lichen, the lignin content is low (4\%), as are all the macronutrients, and the high content of hemicellulose (contained in the aciddetergent fiber fraction) may require a different set of decomposer organisms (Heal et al. 1981).

One recent model for predicting decomposition rates involves annual actual evapotranspiration $(A E T)$ and lignin content (Meentemeyer 1978) and is based on data from five locations, ranging from subpolar to warm temperate. This model has been used for the Schefferville climate (annual $A E T$ estimated to be $300 \mathrm{~mm}$, of which $200 \mathrm{~mm}$ occurs during the summer) and the lignin content of the six tissue types. Predicted mass loss during $1 \mathrm{yr}$ varies from $17 \%$ for the Picea old needles and twigs and Betula leaves to $29 \%$ for the Cladina. The model underestimates the 1-yr decomposition rate for all but one of the tissue types by 5 23\%. The exception is Cladina, which gives a predicted mass loss of $29 \%$ and observed losses of 6,17 , and $11 \%$ on the burn soil site and on top of and beneath the lichen mat, respectively. Reducing the $A E T$ value to the summer value of $200 \mathrm{~mm}$ increases the underestimation of the mass loss of the five tissue types to $11-30 \%$ but reduces the overestimation of the Cladina mass loss to $2-12 \%$. It should be noted that the model has a standard error of the estimate of $10 \%$, while the standard errors of the observed decomposition data range from 0.2 to $4 \%$.

Recently, exceptions to this model have been noted in deserts and clear-cut forests (Whitford et al. 1981), primarily because of biotic adaptations and microclimatic extremes, respectively. For the subarctic woodland, the probable reason for underestimating mass losses is that much of the annual loss occurs beneath the winter snowpack, when actual evapotranspiration values are close to zero.

A significant wintertime mass loss has been observed for litter in other ecosystems (e.g., Bleak 1970, McBrayer and Cromack 1980). Although the climate above the snowpack may be very harsh, snow accumulation starts in early November and reaches a peak value of $1.5 \mathrm{~m}$ in mid-April; subnivean temperatures 
at Schefferville rarely fall below $-3^{\circ} \mathrm{C}$ (Moore, in press). It has been shown that both microorganisms and macrofauna can be active down to $-5^{\circ}$ to $-10^{\circ}$, so that significant amounts of decomposition can occur during the subarctic winter (e.g., Flanagan and Veum 1974, Aitcheson 1979). From the present study, it is not clear whether the major decomposition occurs from September to November; from November to May, the cold period during which the thick snow cover insulates the soil; or during the spring snowmelt. In another study, it is shown that decomposition occurs mainly in the period before snow accumulates (Moore, in press). Thus much of the decomposition of and nutrient release from the litter occurs when plant activities are minimal, further contributing to the oligotrophic status of the system.

The pattern of nutrient release from the decomposing litter shows that $\mathrm{Ca}, \mathrm{Mg}$, and $\mathrm{K}$ are lost readily, presumably through a leaching process, and in the general series: $\mathrm{K}>\mathrm{Mg}=\mathrm{Ca}$. The exception to this pattern is for the Cladina tissue, in which $\mathrm{Ca}$ and $\mathrm{K}$ are rapidly lost, followed by a slower, and more erratic, release of $\mathrm{Mg}$. Thus, these three macronutrients should be rapidly returned to the soil and plant root systems, although the magnitude of winter losses may affect the availability of these nutrients to plants.

The pattern for $\mathrm{P}$ is similar, with $30-70 \%$ of the original $\mathrm{P}$ returned to the soil after $2 \mathrm{yr}$ of decomposition. Again, the Cladina proves to be an exception, with little loss of $\mathrm{P}$. The ready loss of $\mathrm{P}$ from the tissues, suggests that $\mathrm{P}$ is not a critical element in controlling decomposition; C:P ratios range from low values of 235:1 and 343:1 for the Betula and Ledum leaves, respectively, through values of 533:1 to $649: 1$ for the Picea tissues to a high ratio of 1454:1 for the Cladina.

The pattern of $\mathrm{N}$ retention over the 2-yr period in all the tissues, except the Betula leaves, emphasizes the importance of $\mathrm{N}$ to the woodland ecosystem and repeats a pattern of net $\mathrm{N}$ immobilization or accumulation observed in many litter decomposition studies (e.g., Gosz et al. 1973, Swift et al. 1978, Schlesinger and Hasey 1981). In this woodland study, the $\mathrm{N}$ contained in the decomposing tissues increases by up to $200 \%$ for the Picea tissues and Cladina, values commonly recorded in similar litter types (Berg and Staaf 1981). The pronounced increase in $\mathrm{N}$ amount, as well as concentration in the decomposing litter, has been ascribed to three processes: immobilization of $\mathrm{N}$ from atmospheric inputs, immobilization of $\mathrm{N}$ from soil horizons, and fixation of $\mathrm{N}$ from the atmosphere.

Atmospheric inputs of $\mathrm{N}$ to subarctic woodlands are low, given the relatively low levels of pollution and the fact that the canopy drip from spruce canopies falls on only a small proportion of the woodland surface. Away from spruce trees, the annual atmospheric input of $\mathrm{N}$ is $<1 \mathrm{~kg} / \mathrm{ha}$ (Moore 1980). If we assume that all of this $\mathrm{N}$ could be absorbed by the decomposing litter, we can calculate whether this source can make a sig- nificant contribution to the observed increase in $\mathrm{N}$ amount. For the Picea needles and Cladina, at $250 \mathrm{~g} /$ $\mathrm{m}^{2}$ (the value for the tissues contained in the litter bags) and initial $\mathrm{N}$ concentrations of 0.5 and $0.2 \%$, respectively, an annual atmospheric input of $1 \mathrm{~kg} / \mathrm{ha}$ would produce an increase of 8 and $20 \%$ of $\mathrm{N}$ in the litter. These values compare to observed increases, over the 1st yr, of 10-30\% and 50-65\%, respectively, so that atmospheric inputs, alone, cannot account for the accumulation of $\mathrm{N}$ in the decomposing tissue.

The litter samples placed on the surface of the lichen mat show as large an increase in $\mathrm{N}$ amount as those samples placed on the burn soil or beneath the lichen mat. Given the $5-10 \mathrm{~cm}$ distance between the litter bags on the lichen mat and the soil surface, immobilization of $\mathrm{N}$ from the soil seems unlikely, though fungal hyphae have been observed as the major $\mathrm{N}$-accumulating process in a Scots pine forest litter (Berg and Söderström 1979).

There is no direct evidence for $\mathrm{N}$ fixation as the source of the observed increases in the $\mathrm{N}$ content of the decomposing litters. Although dinitrogen fixation rates have been measured on decomposing $P$. mariana needles (e.g., Brouzes et al. 1969, Knowles 1977), the rates are low, and Granhall and Lindberg (1979) were unable to account for increased $\mathrm{N}$ in decomposing Scots pine needles through dinitrogen fixation.

The C: $\mathrm{N}$ ratio is frequently believed to be an important control on the mineralization or immobilization of $\mathrm{N}$ in soils; a ratio of $\approx 25: 1$ is frequently quoted as the critical limit, above which there will be little net mineralization or release of $\mathrm{N}$ (Swift et al. 1979), but there is much variability in this ratio (Berg and Staaf 1981). The Picea and Cladina tissues have very high (>100:1) original $\mathrm{C}: \mathrm{N}$ ratios, show no evidence of net mineralization during the $2 \mathrm{yr}$ of study, and still have high ( $>40: 1)$ ratios after $2 \mathrm{yr}$ of decomposition. On the other hand, the Betula leaves have high (64:1) initial $\mathrm{C}: \mathrm{N}$ ratios yet lose large amounts of $\mathrm{N}(30-45 \%)$ after 21 mo, by which time the $\mathrm{C}: \mathrm{N}$ ratio has fallen to 35 : 1-63:1. From 21 to 24 mo, however, there appears to have been an increase in $\mathrm{N}$ amount in the Betula leaves, back to values close to the original quantity though there are high standard errors for all sampling dates.

The tissue with the lowest original $\mathrm{C}: \mathrm{N}$ ratio $(39: 1)$, the Ledum leaves, exhibit a variable pattern, with high standard errors for all sampling dates but do not show large amounts of net $\mathrm{N}$ mineralization, though the $\mathrm{C}: \mathrm{N}$ ratio has reached $20: 1$ after $2 \mathrm{yr}$. Thus, there is no strong evidence for the $\mathrm{C}: \mathrm{N}$ ratio acting as a dominant control over the fate of $\mathrm{N}$ in the decomposing tissues.

These results, then, show that litter decomposes slowly in subarctic woodlands, though there are considerable differences between the different tissue types. For all litter types, except Cladina, location of the litter at a burnt site, or on top of or beneath the lichen mat makes little difference to the decomposition rate, 
but much of the decomposition occurs during the winter (September to June). $\mathrm{Ca}, \mathrm{Mg}, \mathrm{K}$, and $\mathrm{P}$ are rapidly lost from the decomposing tissues, except for Cladina, while $\mathrm{N}$ is accumulated in the tissues, except for Betula. $\mathrm{N}$ tends to become bound up in the soil organic matter, rather than being released for plant uptake. This finding agrees with the response of Picea, Ledum, and Betula to $\mathrm{N}$ fertilization, noted above, and to the distribution of nutrients within the ecosystem.

\section{ACKNOWLEDGMENTS}

The author gratefully acknowledges the laboratory assistance of Jamshed Merchant, the logistical support of the McGill Subarctic Research Station, and the financial support of the FCAC program, Ministère de l'Education, Gouvernement du Québec.

\section{Literature Cited}

Aitcheson, C. W. 1979. Winter-active subnivean invertebrates in southern Canada. Pedobiologia 19:113-120, 121$128,153-160,176-182$.

Anderson, J. M. 1973. The breakdown and decomposition of sweet chestnut (Castanea sativa Mill.) and beech ( $\mathrm{Fa}$ gus sylvatica L.) leaf litter in two deciduous woodland soils. II. Changes in the carbon, hydrogen, nitrogen and polyphenol content. Oecologia (Berlin) 12:275-288.

Barr, D. R., and R. K. Wright. 1981. Selected climatological data, 1955-1980, for the Schefferville (A) Station. McGill Subarctic Research Paper 32:117-134.

Berg, B., and B. Söderström. 1979. Fungal biomass and nitrogen in decomposing Scots pine needle litter. Soil Biology and Biochemistry 11:339-341.

Berg, B., and H. Staaf. 1981. Leaching, accumulation and release of nitrogen in decomposing forest litter. Pages 163 178 in F. E. Clark and T. Rosswall, editors. Terrestrial nitrogen cycles. Processes, ecosystem strategies and management impacts. Ecological Bulletin 33, Swedish Natural Science Research Council, Stockholm, Sweden.

Bleak, A. T. 1970. Disappearance of plant material under a winter snow cover. Ecology 51:915-917.

Brouzes, R., J. Lasik, and R. Knowles. 1969. The effect of organic amendment, water content, and oxygen on the incorporation of $\mathrm{N}$ by some agriculatural and forest soils. Canadian Journal of Microbiology 15:899-905.

Canada Soil Survey Committee. 1978. The Canadian system of soil classification. Canada Department of Agriculture Publication 1646, Ottawa, Canada.

Carstairs, A. G., and W. C. Oechel. 1978. Effects of several microclimatic factors and nutrients on net carbon dioxide exchange in Cladonia alpestris (L.) Rabh. in the subarctic. Arctic and Alpine Research 10:81-94.

Cowles, S. 1982. Preliminary results investigating the effect of lichen ground cover on the growth of black spruce. Naturaliste Canadian 109:573-581.

Dubreuil, M. A., and T. R. Moore. 1982. A laboratory study of post-fire nutrient redistribution in subarctic sprucelichen woodlands. Canadian Journal of Botany 60:25112517.

Edmonds, R. D. 1979. Decomposition and nutrient release in Douglas-fir needle litter in relation to stand development. Canadian Journal of Forest Research 9:132-140.

Flanagan, P. W., and A. K. Veum. 1974. Relationships between respiration, weight loss, temperature and moisture in organic residues in tundra. Pages 249-278 in A. J. Holding et al., editors. Soil organisms and decomposition in tundra. Tundra Biome Steering Committee, Stockholm, Sweden.

Goering, H. K., and P. J. van Soest. 1970. Forage fibre analysis. United States Department of Agriculture Agriculture Handbook 379.

Gosz, J. R., G. E. Likens, and F. H. Bormann. 1973. Nutrient release from decomposing leaf and branch litter in the Hubbard Brook forest, New Hampshire. Ecological Monographs 43: 173-191.

Granhall, V., and T. Lindberg. 1977. Nitrogen fixation at coniferous forest sites within the Swecon project. Technical Report 11, Swedish Coniferous Forest Project, Stockholm, Sweden.

Graustein, W. C., K. Cromack, and P. Sollins. 1977. Calcium oxalate occurrence in soils and effect on nutrient and geochemical cycles. Science 198: 1252-1254.

Heal, O. W., P. W. Flanagan, D. D. French, and S. F. MacLean. 1981. Decomposition and accumulation of organic matter in tundra. Pages 587-633 in L. C. Bliss, O. W. Heal, and J. J. Moore, editors. Tundra ecosystems: a comparative analysis. International Biological Programme 25, Cambridge University Press, New York, New York, USA.

Heal, O. W., and D. D. French. 1974. Decomposition of organic matter in tundra. Pages 249-277 in A. J. Holding et al., editors. Soil organisms and decomposition in tundra. Tundra Biome Steering Committee, Stockholm, Sweden.

Hesse, P. R. 1971. A textbook of soil chemical analysis. J. Murray, London, England.

Holding, A. J., O. W. Heal, S. F. MacLean, and P. W. Flanagan. 1974. Soil organisms and decomposition in tundra. Tundra Biome Steering Committee, Stockholm, Sweden.

Knowles, R. 1977. The significance of asymbiotic dinitrogen fixation by bacteria. Pages $33-83$ in R. W. F. Hardy and A. H. Gibson, editors. A treatise on dinitrogen fixation. Section IV: agronomy and ecology. J. Wiley and Sons, New York, New York, USA.

Lucarotti, C. J. 1981. The effect of forest regeneration on mesofauna populations and microfungal species in lichen woodland soils. McGill Subarctic Research Paper 32:7-26.

McBrayer, J. F., and K. Cromack. 1980. Effect of snowpack on oak-litter breakdown and nutrient release in a Minnesota forest. Pedobiologia 20:47-54.

Meentemeyer, V. 1978. Macroclimate and lignin control of litter decomposition rates. Ecology 59:465-472.

Melillo, J. M., J. D. Aber, and J. F. Muratore. 1982. Nitrogen and lignin control of hardwood leaf litter decomposition dynamics. Ecology 63:612-626.

Middleton, K. R. 1960. New Nessler reagent and its use in the direct Nesslerization of Kjeldahl digests. Journal of Applied Chemistry 10:281-286.

Moore, T. R. 1980. The nutrient status of subarctic woodland soils. Arctic and Alpine Research 12:147-160.

1981. Controls on the decomposition of organic matter in subarctic woodland soils. Soil Science 131:107113.

- In press. Winter-time litter decomposition in a subarctic woodland. Arctic and Alpine Research.

Olson, J. S. 1963. Energy storage and the balance of producers and decomposers in ecological systems. Ecology 44:322-331.

Piene, H., and K. van Cleve. 1978. Weight loss of litter and cellulose bags in a thinned white spruce forest in interior Alaska. Canadian Journal of Forest Research 8:4246.

Rencz, A. 1976. The level and distribution of biomass and nutrients in a subarctic lichen woodland. Thesis. McGill University, Montreal, Canada.

Rosswall, T. 1974. Cellulose decomposition studies on the tundra. Pages 325-340 in A. J. Holding et al. editors. Soil organisms and decomposition in tundra. Tundra Biome Steering Committee, Stockholm, Sweden.

Rouse, W. R., and K. A. Kershaw. 1971. The effects of 
burning on the heat and water regimes of lichen-dominated subarctic surfaces. Arctic and Alpine Research 3:291-304.

Schlesinger, W. H., and M. H. Hasey. 1981. Decomposition of chaparral shrub foliage: losses of organic and inorganic constituents from deciduous and evergreen leaves. Ecology 62:762-774.

Soil Survey Staff. 1975. Soil taxonomy. United States Department of Agriculture Agriculture Handbook 436.

Swift, M. J., O. W. Heal, and J. M. Anderson. 1979. Decomposition in terrestrial ecosystems. Volume 5. Studies in ecology. Blackwell, Oxford, England.

Van Cleve, K. 1974. Organic matter quality in relation to decomposition. Pages 311-324 in A. J. Holding et al., editors. Soil organisms and decomposition in tundra. Tundra Biome Steering Committee, Stockholm, Sweden.
Weetman, G. F. 1965. The decomposition of confined black spruce needles on the forest floor. Woodlands Research Index No. 165. Pulp and Paper Research Institute of Canada, Montreal, Canada.

Werren, G. L. 1978. Winter stress in subarctic spruce associations: a Schefferville case study. Thesis. McGill University, Montreal, Canada.

Whitford, W. G., V. Meentemeyer, T. R. Seastedt, K. Cromack, D. A. Crossley, P. Santos, R. L. Todd, and J. B. Waide. 1981. Exceptions to the AET model: deserts and clear-cut forest. Ecology 62:275-277.

Wright, R. K. 1981. The water balance of a lichen tundra underlain by permafrost. McGill Subarctic Research Paper 33: $1-110$. 